\title{
Chafing borderlands: obstacles for science teaching and learning in preschool teacher education
}

\author{
Kristina Andersson ${ }^{1}$ (D) - Annica Gullberg ${ }^{1} \cdot$ Anna T. Danielsson $^{1}$. \\ Kathryn Scantlebury ${ }^{1}$ - Anita Hussénius ${ }^{1}$
}

Received: 1 November 2017 / Accepted: 11 March 2019 / Published online: 5 June 2019

(c) The Author(s) 2019

\begin{abstract}
This study examines preservice preschool teachers' university science education experience. The empirical data are from a research and intervention project conducted on teacher education programs at two Swedish universities. We analyzed one of the assignments completed by 111 students within a science course as well as their conversations about the assignment at a number of seminars. We combined culture contrast and thematic analysis to examine the data. The results showed a tension between the preschool culture and the university science culture. We described this tension between the boundary lines of the two cultures as a chafing borderland. These cultures do not merge, and the defined boundaries cause chafing with each other. We discuss ways of diminishing this chafing of borderlands, potential border crossings such as caring and children as boundary objects and equalizing power imbalances.
\end{abstract}

Keywords Culture contrast - Preschool culture $\cdot$ Preservice preschool teachers $\cdot$ Science culture $\cdot$ Teacher education

For teachers, it is important to gain knowledge about possible obstacles to student learning and strategies to overcome those barriers. Similarly, it is important for university teachers to know what may create difficulties for teacher students in teacher education, especially since they otherwise can bring these difficulties into their future profession. Research about primary and preschool teachers and science has shown that these teachers have limited subject knowledge and low self-esteem, particularly when teaching physics and chemistry, which can lead teachers to avoid these topics (Spector-Levy, Kesner Baruch and Mevarech 2013). Many science teacher educators and researchers have a background in the natural sciences and a passion for, and commitment to, their subjects. Their starting point is often that if students can just experience teaching that engages them, they will understand how exciting and interesting science is which would lead to an increase in their science

Lead Editor: Bronwen Cowie.

Kristina Andersson

kristina.andersson@gender.uu.se

1 Centre for Gender Research, Uppsala University, Box 527, 75120 Uppsala, Sweden 
knowledge. Student teachers specializing in preschools and early childhood education probably have other motivations for their choice for education, namely children's development and needs.

The aim of this study is to examine how university science is perceived by preschool teacher students in relation to other areas of knowledge in their education and the ways that contradictions emerged. Furthermore, this study identifies factors that may be of importance for overcoming these contradictions.

\section{Early childhood preservice teachers' science education}

Many primary teachers have had negative science schooling experiences and consequently have avoided science in higher education (Andersson and Gullberg 2014). As such, one challenge for teacher education programs is to highlight the importance of science for preservice teachers, develop their science content knowledge and attitude and assist preservice teacher to gain self-confidence in teaching science to meet the educational needs of their future students. However, some researchers have different approaches in dealing with this problem. For example, Peter Fensham (1991) drew attention to early childhood preservice teachers' preoccupation that they had not studied chemistry and physics rather than highlighting what they knew in biology. Bodil Sundberg and Christina Ottander (2013) stated that knowledge of different learning cultures may be helpful for educators to work together with preschool teachers to develop science education for preschool. They investigated how preschool teacher students' perceptions of science changed during their preparation. In questionnaires, a majority of the preservice teachers expressed positive attitudes toward doing science activities with children. However, these preservice teachers showed a reluctance to actually teach science. They viewed science teaching as dogmatic and authoritarian, the antithesis of the preschool's mission, to care for young children. Also Marilyn Fleer (2006) highlighted that preschool student teachers encountered two different cultures, namely, "Science Education" and "Early Childhood Education" during their training. She argued that during training these student teachers needed to move from being peripheral members of the science education culture to full membership. Fleer (2006) noted the lack of research on how to support student teachers in crossing the boundaries between the early childhood education and science education cultures.

\section{Using culture as an analytical construct}

In the following section, we describe science and preschool cultures that student teachers are likely to encounter in their education.

\section{Science as a culture in Western world}

In this article, we use William Cobern and Glenn Aikenhead's (1998) conceptualization of culture and the learning of science as the enculturation into this culture as our theoretical starting point. We also benefited from Cathrine Hasse's (2015) concept of culture as a theoretical/analytical construct, a "mental construction" for understanding what happens in preschool teacher education. As members of a culture, its processes and habits are incorporated into our minds and bodies, making them largely invisible to us (Hasse 2015). We 
enter as a cultural novice and gradually become more experienced. Cobern and Aikenhead (1998) have highlighted the importance of the culture of science for learning science. They describe science as a Western cultural icon when coupled with the progress, power and prestige. In school, the communication of scientific culture to students can either be supportive or disruptive. If the scientific culture is in harmony with the student's everyday culture, then science education supports the student's world view, resulting in enculturation. However, if the scientific culture and the student's everyday world are different or in conflict, then the science teaching generates dissonance in the student's perception of the world. To understand how students enter (or are unable to enter) into the culture of science, Cobern and Aikenhead (1998) as well as Lars Krogh and Poul Thomsen (2005) use Patricia Phelan, Ann Locke Davidson and Hanh Thanh Cao (1991) concepts of "cultural borders" and "border crossing." According to Phelan et al. (1991), these concepts are a way to illustrate the students' problems in accessing to scientific culture. Victoria Costa (1995) and later Aikenhead (2001) used the backgrounds of high-school students interested in science to step over cultural boundaries between everyday cultures to school science. Costa (1995) described five ways students related to school science: (1) potential scientists, (2) other smart kids, (3) "I don't know" students, (4) outsiders and (5) inside outsiders. Later, Aikenhead (2001) proposed a sixth category, "I want to know" students. Emily Kang, Julie Bianchini and Gregory Kelly (2013) used border crossing to describe the transition from being a science student to an inquiry-oriented science teacher. They conclude that both teacher educators and teacher students can benefit from making the border between learning and teaching explicit. Cobern and Aikenhead (1998) concluded that teachers should explicitly assist students to step over these borders.

Cobern and Aikenhead (1998) paid attention to the imbalance of power between Western culture and other cultures, but science's elitist overtones also have consequences for individuals working within a Western context. For nearly four decades, feminist scholars have critiqued the culture of science as a male domain and have examined structures within science that have excluded, ostracized and/or subordinated women. Critique from feminist philosophers like Donna Haraway (1988) challenges the view of natural sciences as objective and argues that this kind of knowledge production is made from human activities that are socially and culturally situated. One notable problem in science is its elitist image. Science is perceived as difficult and demanding, requiring a special talent from those who want to study or engage with the subject. Implied is the idea that it is not possible for everybody to engage with science, and this exclusiveness primarily affects women and men from underrepresented groups. Abilities and skills that are valued in these areas can be associated with masculinity. Therefore, feminist science educators suggest that students' declining interest is due to "the nature" of the disciplines (Scantlebury 2012).

The subordination of women operates in thought structures on a symbolic level. Since science subjects hold masculine connotations, feminist theory is appropriate in the present study in that it provides a way to make gendered power dimensions explicit in the analysis. With historian Yvonne Hirdman's understanding of the gender order, the notions of suitability, aptitude and other human characteristics are tied to gender on a symbolic level, in our thought structures, which have an impact structurally in society and individually (Hirdman 2001). The links between science and gender at the symbolic level may also be important for an individual's performance in subject areas (which in psychological research is referred to as "stereotypical threat"; see, for example, Schmader and Johns 2003). Hirdman (2001) describes the all-encompassing tragedy of the constant surfacing of gender, in the binary division of gender and the boosting of male over female, and then the inevitable contempt for what is considered the "female." The contempt becomes an essential position 
to perpetuate the subordination of women and the socialization of women and men in this order. Therefore, women themselves, consciously or unconsciously, and in various degrees, carry a self-loathing that must be handled and vigorously resisted for this not to be selfloathing directed outward toward the children/students (Andersson 2012).

\section{Preschool as a culture in Nordic countries}

The Swedish preschool system has a more than 100-year history, with roots that include Friedrich Fröbel's and Ellen Key's traditions of thought that still today influence its culture. Gunilla Halldén (2007) pointed out that this tradition is characterized by a holistic view of the child, where daily care, cooking and hygiene are of equal importance as play and other creative learning activities. This can be compared with school, which focuses on the child's cognitive development in a system clearly divided by topic with performance requirements (Vallberg Roth 2002). The child in preschool is seen as autonomous, competent and active, as the creator of her or his own knowledge, culture and identity (Corsaro 2005). In Sweden today, preschool placements are offered to all children, 1 year old and up, at minimal cost to families. Eighty-four percent of children ages 1-5 years old and $95 \%$ of children between 4 and 5 years old attend preschool (The Swedish National Agency for Education 2016). Ninety-six percent of preschool teachers and childcare assistants are women, and $39 \%$ of these teachers have a higher education degree in early childhood education (The Swedish National Agency for Education 2016).

Care and education have always been key areas but with different emphases at different times. The interconnection between these two parts has given international attention under the term edu-care (Swedish Schools Inspectorate 2012). However, care and teaching have had different gendered connotations, where the area education historically was a male domain while care is seen as linked to the female and primarily associated with the nurturing portions of the program (Johansson and Pramling Samuelsson 2001). In addition, today there is debate about these two areas in preschool and what the hierarchy between them ought to look like (Halldén 2007). Annika Månsson (2000) noted that the concept of teaching and learning dominates, while concepts such as care and nurturing play more modest roles in the preschool curriculum.

The dilemma that preschool is not just a social care institution but also a school must be handled by preschool teachers in practice. The strong value placed on a holistic approach to children and the idea of the competent child has long identified the preschool culture distinguished from school culture. Preschool teachers are concerned that preschool will be identified with school, thereby creating increased demands within the subject contents of the curriculum for preschools (Andersson and Gullberg 2014).

\section{The intervention project and the research context}

This paper focuses on preschool student teachers' cultural experiences they encounter during their education, with a particular focus on potential chafing between cultures and how those chafings may be reconciled. In order to explore this research aim, we make use of empirical data collected within the research and intervention project, "Challenging science teacher education." Below we outline this project and its methodological foundation before 
moving on to a description of the empirical data used in this particular paper as well as how those data were analyzed.

This article used empirical data from a research and intervention project conducted during 2011-2013 at two Swedish universities' teacher education program. In Sweden, this teaching degree is an academic professional education where students studied for three and a half years to teach preschool or primary school. The intervention was carried out during two semesters when the students began courses in science. In addition to the science content, gender/feminist perspectives on scientific activities were introduced as tools to identify and analyze science culture. One aim of the intervention was to help students reflect on their science attitudes but also to provide a different view of themselves in relation to the subjects. Before the intervention, the researchers informed students about the purpose and research methodology and collected written consent for participation. The few students who withheld their consent were placed together in a separate group during recorded sessions. Our methodological design of the intervention was based on feminist theory in order to problematize science education and to include critical perspectives in teaching (Capobianco 2007). A feminist approach visualizes and discusses cultural, social and historical dimensions of science, which have also proved helpful for gaining knowledge of subject matter content, as Jill Sible, Dayna Wilhelm and Muriel Lederman have shown in their study "Teaching Cell and Molecular Biology for Gender Equity" (2006). For a more detailed description of the intervention, (see Hussénius et al. 2015).

In this article, we analyze one of the students' assignments on science culture's visibility and their conversations about the assignment at a number of seminars. After introductory theory sessions on the history and culture of science, the students analyzed sections from different textbooks in biology, physics and chemistry. Afterward, the groups reported their analyses orally to each other and discussed their observations. The work was followed by an individual observation assignment to try to create a view of the scientific culture and get at which stories are told in parallel with the content knowledge that were presented (see "Appendix 1"). The students could choose to observe and analyze science education within a course they were enrolled in, science teaching during their (pre)school placement, review text-based teaching materials, or a laboratory activity or excursion. The information was presented in writing and orally at a subsequent seminar.

\section{Data collection and analysis}

The empirical material consists of 111 students' individual written observation data submitted as a course assignment, $440 \mathrm{~min}$ of audio-recorded group discussions and the researchers' written field notes from seminars. The students were made anonymous but coded so that data from the same student have the same code.

Virginia Braun and Victoria Clarke's thematic analysis (2006) was used as a fundamental analysis tool as well as the software package QSR NVivo 9 to code data into nodes, categories and themes. The analysis began with repeated readings of students' texts, researchers' field notes and transcriptions of recorded group discussions about their assignments, in order to get both an overview and deeper knowledge of the empirical material. Through an iterative coding process of texts, different parts were coded and linked to sets designated with a recognizable description. These sets and designations were refined further, resulting in categories and subcategories. In some cases, the process led to the relocation of material within the categories and subcategories as well as the creation or reformulation of categories. From this categorization, the material was searched repeatedly to find common 
themes. After the initial thematization, a deeper theoretical analysis within each of these themes was made, where we used Cathrine Hasse and Stine Trentemøller's "method of culture contrast" (2009). In this method, practices (e.g., the scientific disciplines and the preschool teacher education) are conceptualized as "cultures," with their own implicit and explicit rules as well as different values and underlying assumptions. Furthermore, when cultures are contrasted, it is possible to see the different values and norms that are dominated or ignored. The different actors that are part of a culture are understood as "carriers" of the culture's underlying ideas, which in different ways are manifested in their actions. Through these actions, it is possible to uncover these tacit assumptions (Hasse and Trentemøller 2009).

The following example of our observation at a seminar in a preschool educational course taken by the students in parallel with one of the science courses illustrates how we used the culture contrast method in our analysis of the empirical data:

When we came into the classroom the blinds were pulled down and the lights were off. On a desk a candle was burning, and around the light the faculty ${ }^{1}$ had arranged clusters of rowan berries and leaves. She welcomed the students. The darkened, cozy classroom muted students' voices and even the faculty spoke in a soft, whispering voice. (Field notes, September 20, 2011)

With a background in the natural sciences and the prior understanding it brings, this presentation on the professor's desk could indicate that the faculty will do a science-related experiment with light and/or leaves and berries or discuss a topic in biology that deals with nature in autumn. However, the researchers, who have science backgrounds, knew the faculty's intentions with these elements instead were to create a welcoming, inviting atmosphere for students in the classroom. Based on our science education experiences, it is unusual for faculty to take elements of nature to decorate or create a mood in the classroom. For us, this presentation stood out; it was something unexpected and an example of a different culture with different values from the scientific. In the analysis of students' texts and statements, we then looked for actions and recurring concepts that "attracted attention," that is, that stood out and in that way identify what can be considered typical of a certain culture and not another.

The method of culture contrast together with the use of the analytical concepts of border crossing (Cobern and Aikenhead 1998) and boundary objects (Star and Griesemer 1989) brought to the fore how the student teachers related to different cultures they encountered and how these cultures related to one another. The boundaries between cultures occurred where various aspects such as traditions, artifacts, values and language differed. A person must be aware of and understand these aspects to cross over the boundary. Among the many different objects and phenomena, some of these are recognizable in many different cultures and can serve as bridges, called boundary objects. Boundary objects are used in educational research to describe a physical or mental artifact that helps to bridge the different practices and thus can facilitate learning and understanding between different groups (Akkerman and Bakker 2011).

\footnotetext{
1 In this article, the university teachers are alternately/interchangeable called faculty or professor and they can hold the positions lecturer, senior lecturer or professor.
} 


\section{Identifying and reducing chafing between science and preschool cultures}

The results from the analysis of students' assignment are divided into two main themes: how the chafing presents between the two cultures and strategies to reduce the chafing. These themes are presented below under the headlines How the chafing emerges between the culture of university science and the culture of preschool and Potential border crossings - ways of diminishing chafing of borderlands, respectively.

\section{How the chafing emerges between the culture of university science and the culture of preschool}

When the assignment about trying to recognize scientific culture was presented orally at one of the seminars, a big emotional response was observed when the preschool teacher students realized they could choose to analyze their own experiences of university science teaching. In her field notes after the seminar, the author describes what happened in this situation:

It felt like pulling the cork out of a champagne bottle. The students began speaking excitedly with each other. They asked if they really could choose to observe their classes at university. I said, "absolutely, of course," and it lifted the tone in the room. One student told me that they had had a teacher who made condescending comments about the student group and that they felt talked down to, "what did that say about what the teacher wanted to convey?" They also asked about turning the assignment in. (Field notes from the seminar, 14 March 2011)

The task filled an unmet need of preschool student teachers to share experiences from their university education.

Table 1 shows which areas the students mapped as science culture. There is a difference between preschool and primary school student teachers' basic choices.

Almost $60 \%$ of preschool student teachers chose to "capture science culture" at a lecture at the university, while only $9 \%$ of primary school student teachers chose that option. Of primary school student teachers, $72 \%$ chose to analyze teaching materials, compared with $23 \%$ of preschool teachers. There are probably several reasons why the primary school student teachers made this choice. The textbooks are the books that these teachers' prospective students will use, and the student teachers can thus have reasoned that it is appropriate to have studied parts of them in more detail. At the seminar, the students did textual analyses of textbooks, so another reason may be that the students felt more prepared to conduct the analysis.

In the analysis of preschool student teachers' assignments, a tension emerged between the preschool culture, where preschool science is included, and the university science culture. We use the term chafing borderlands to highlight the boundary line between these two cultures. They do not merge; they do not fuse. Instead, the boundaries are marked, causing chafing with each other. Since preschool student teachers' experiences to a greater extent than the primary school student teachers' can be described with the term chafing borderlands, a borderland between preschool culture and academic science culture, we will henceforth focus at the preschool student teachers in this article. One student explicitly wrote about science as a culture "difficult to penetrate." She 


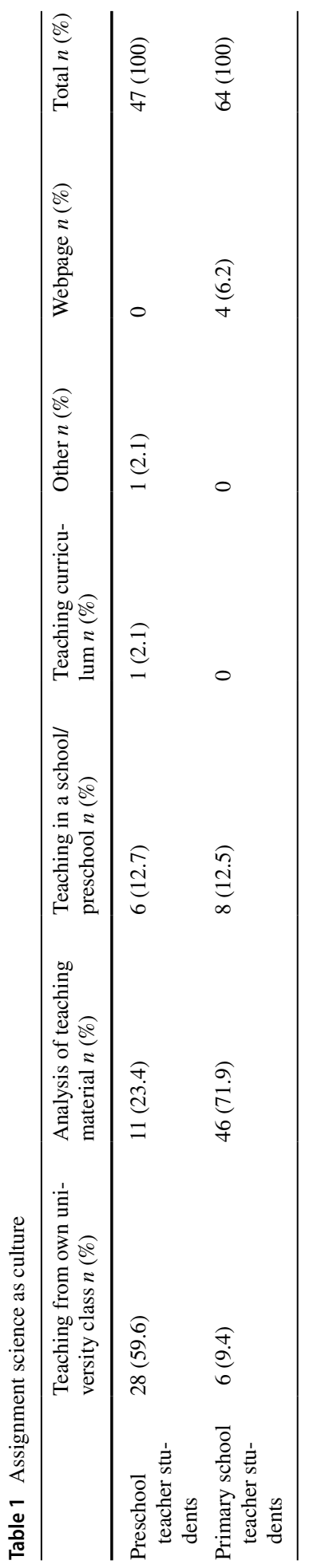


asserts that this is some kind of "border" that needs to be crossed in order to assimilate subjects:

The science world is surrounded by a particular culture, and it can be difficult to grasp all the concepts, theories and rules. [...] science culture can be difficult to elbow your way into if you lack the skills and experience. It can seem incomprehensible, alien and frightening. What I mean is that some of my fellow students were thrown into a world they might not have been in for many years. (Student 1)

Nor is it obvious that the students during this academic year stepped over the border into the scientific culture. Judith Mulholland and John Wallace (2003) described that teacher students have to make multiple border crossings, and one being the step from being a student to a school teacher, that is, from preservice to in-service. In our data set, the education culture and professional culture are more closely related than in Mulholland and Wallace's study (2003) and do not create a border crossing that poses difficulties for these students. There may be several reasons for this. One is that a large proportion of preschool student teachers had previous experience working in a preschool as nannies and has thus already been introduced to preschool culture. The students have embraced the way the professional culture presents and what it means, and strongly identify with it. Another reason may be that many of the faculty who teach more "pure" early childhood education courses have backgrounds as preschool teachers and still identify strongly with their previous professions. When they got their own education, it was influenced by a profession as preschool teachers primarily related to care, and they also bring this perspective to education, now as university professors. Care is also central in their interactions with preschool student teachers and was noted by two of the authors when they observed a seminar in a preschool education course concurrent with one of the science courses. The situation was described earlier to illustrate the methodological cultural contrast, but it is presented below in more detail. One of the authors describes the start of the seminar in her field notes:

When we came into the classroom the blinds were pulled down and the lights were off. On a desk a candle was burning, and around the light the faculty had arranged clusters of rowan berries and leaves. She welcomed the students. The darkened, cozy classroom muted students' voices and even the faculty spoke in a soft, whispering voice. She said that the seminar would focus on children in vulnerable situations, and they would watch a movie about this. [...]The faculty, who was approaching retirement age, described her own experiences from when she worked at preschool, how she preferred to sit down on the floor in the group of children, and immediately the children crawled up in her lap or sat next to her. Students murmured and nodded while she was talking, so there was a strong sense of consensus in the classroom. (Field notes from September 20, 2011)

The professor invited students to come together as equals. The teaching was largely narrative, based on faculty's own experiences from preschools, in which the students could recognize themselves. At a first glance, the "cozy" atmosphere at the seminar promotes a positive learning environment, but it can have negative consequences for the intellectual exchange in that it inhibits the critical attitude, one of the goals in university teaching. The preference in preschool culture will be not to spoil the pleasant atmosphere by performing a critical point of view, but rather to agree with each other, which is reflected in the students' humming. It is assumed that the discourse of caring and coziness is positive for all kinds of students and should be applicable also for university education. At university level, one expectation at a seminar is to have theoretical 
discussions and argumentations in order to deepen the knowledge and challenge students' presumptions. The repeated actions regarding caring in different situations during preschool teacher education, a performativity act (Butler 1990), construct the science culture as something strange, something "other" that chafe within preschool teacher education.

\section{Power imbalances cause the chafing between the culture of university science and the culture of preschool}

Of the 28 preschool student teachers choosing to analyze their own university education (Table 1), a majority of them (17 students) identified problems to their science learning. Five students presented a nuanced picture of science, describing both its merits and weaknesses, while six students described the science teaching in exclusively positive terms as stimulating and instructive. The students' university science education included lectures on physical geography, plants and photosynthesis, environment, ecology and practical exercises such as a birding excursion, a physical geographical excursion and a geology laboratory on minerals and rocks. In many of the students' texts describing their university education, power imbalances emerge as a chafing between the two cultures. In different ways, students describe science as exclusive and elitist, and the professors often reproduced these elitist tones. The scientific language, with its precise terms, is also a barrier and contributes to the idea that the teaching is at too high a level, and this leads to students' feeling stupid:

X's lecture on ecology was at a higher level than what we students could understand. We had to ask many "unnecessary" questions because X's knowledge in the field is so incredibly high and the facts she applied were probably so obvious to her but somewhat incomprehensible to us because this professor's use of terminology in ecology. However, using other more simplified words, I believe that the lecture would have gotten full marks. (Student 2 on an ecology lecture)

In this description, "high" can be interpreted as an expression of a perceived hierarchy in which the professor holds the higher position because of her scientific knowledge. However, the student sees opportunities to equalize this hierarchy if the professor becomes more conscious about the words she uses.

That a university professor possesses more knowledge in science than the students is expected, but the students' essays have descriptions where the professor is also positioning her-/himself as superior to the students, by explicitly talking down to students. When the course began, the students had low self-esteem regarding their own scientific knowledge, and the professor's approach reinforced their feelings of stupidity:

But something I particularly noticed was that in the beginning he said to us something like, "think about how it looked at this place 6000 years ago, 4000 years ago, 3000 years ago and 1000 years ago. Then we'll get together in groups and see what you come up with." When we reconvened and brought our ideas, he "explained" it to us condescendingly because we or at least I am not so familiar with what it looked like in this location many years ago. [...] What happened was, it was like he was "cutting us down to size" a little. Instead of highlighting the things that were good, he remarked on what we didn't know. I began to feel uncomfortable and took a step backward rather than forward during this excursion when I felt like I didn't want to make a fool of myself again. (Student 3 about the physical geography excursion) 
In the description, the professor did not make an effort to bridge the knowledge gap between him and the students. Instead, he is perceived to use terms of knowledge to his advantage and make statements to show the students as ignorant and position him as more knowledgeable. This approach is in contrast with the preschool professor's lecture (described earlier) who created an intimate atmosphere by using candlelight and other props. In that situation, the professor spoke to the students in a dialogue and she encouraged students to give examples from their own experiences. The students nodded and murmured when the professor described situations that they recognized. Instead of using a subject-based theoretical concept approach relevant within the area of teaching, the professor began from the student teachers' experiences, and this teaching strategy flattens the hierarchy between teacher and students.

Students' descriptions of the science professor's pedagogical approaches show faculty that are primarily focused on conveying certain knowledge content regardless of the students' prior knowledge, where students' commitment or previous experience is secondary. The students' stories give glimpses of a positivist epistemology where scientific facts appear to be objective and true, and this raises science to be undeniable. This epistemological gap is another aspect that contributes to the power shift in which the female students' disadvantage becomes more pronounced. When these preschool student teachers are met with condescending attitudes, where (lack of) knowledge in science subjects is used as a weapon, the gender order becomes doubly noticeable. Science has historically been the preserve of men and skills that are considered in these areas can thus be associated with masculinity (Brickhouse 2001). The consequences are that the students feel personal guilt that they have a lack of knowledge, something they cannot fend off when they don't have explanatory tools on a structural or symbolic level (Hirdman 2001).

\section{Feelings of belonging to preschool culture reinforces alienation toward science teaching}

Academic science generates negative emotions for some students; they lose the desire to learn new things and worry that they do not understand the concepts. Instead, they identify strongly with the preschool culture, and in their essays they equate their own knowledge building with the children's, which we see as a strategy to avoid chafing with the scientific culture.

The students in the following excerpt have a strong idea of what science in preschool should be, and the science they now encountered at a university level was different from what they need to teach science. There appears to be an impermeable boundary between the two cultures:

Only when I looked through the syllabus, I put it together pretty quickly again, this was probably wrong, I thought. This is for student teachers at the upper secondary level, but I will be working with preschoolers. [...] I had a hard time motivating myself to read through the text. [...]I also believe that my profession, to work with children from 1 to 7 years, affects what I want to learn. I don't have enough energy for this. (Student 4)

But sometimes I wonder if I'm really studying for preschool or if I should become a professor of some kind. So who is this appropriate for when I get knowledge about new things that I can't convert and use when I'm out working in a preschool? (Student 3) 
The strong sense of belonging to the preschool culture can be seen as a contributor to the chafing with academic science culture, and it creates notions about what learning should occur. Student 4 describes an almost shocking first encounter with the literature that she believes applies to students who will teach at the upper secondary level. Her description shows that she believes that the course content level is too high, and with that she loses her motivation to learn. She explains that her focus on younger children affects what she wants to learn. Student 3 also thinks that the skill level is too high for preschool teacher training. She comments on the knowledge hierarchy by saying her studies could educate her to be a professor, the highest position in academia. The short excerpt also shows that she believes that the academic scientific knowledge needs to be transformed to fit the preschool context. Several of the students commented that the knowledge content of the science courses had many complicated, arcane concepts or too few explanations. They feel that they could gain knowledge better and be more interested in science if they had studied other types of literature, or if university studies were hands-on and applicable to the profession.

\section{The Janus face of emotions}

Whether students described teaching situations in positive or negative terms, they were very emotionally involved. The task was to analyze the scientific culture, but what was central to most of the students' essays are the descriptions of their feelings linked to the analyzed situation. Caring is fundamental in a preschool teacher's profession, and that includes emotional presence, holistic thinking and mutual understanding for each other (Johansson and Pramling Samuelsson 2001). Aligned with preschool culture, students are acting appropriately when they express their emotions during a task at the university because they are practicing the skills needed for care. But in the teaching profession it is not enough to be empathetic and emotional. Students must also master the skills of analytical thinking, where both their own and others' emotions can be subject to analysis. Otherwise, the risk is that they become trapped in the emotional state that can arise, and they may find it difficult to distance themselves to evaluate these situations.

The emotions in the students' texts are also at odds with what is expected in the science culture. Scientific language does not include emotion, but it is objectively unadorned, often written in the passive voice, with an invisible subject. Emotions in analytical texts in science can be perceived as a lack of understanding of the culture. Thus, it also becomes an expression of the friction between preschool and scientific cultures.

\section{Potential border crossings: ways of diminishing chafing of borderlands}

We have described the chafing between the two cultures and how it became an obstacle to students' engagement and learning in science. In the following section, we use the students' texts to identify aspects that can reduce the chafing.

\section{The cultures' commonalities: showing care for children-showing care for the subject}

The power imbalance between professors and students found in many of the texts is mainly about access or lack of access to scientific knowledge. But some students also wrote about a distance between professors and students caused by the different pedagogical expectations and approaches and whether students feel included in the professor's assignment. 
Therefore, this section will start with an example of the professor's importance in students' (dis)engagement.

The situation below is about a birding excursion, where the student in the text puts emphasis on describing the professor's approach:

When we get to the bird tower, it's so high and the stairs up are steep, so there are a few of us who don't dare to go up. [...] This lesson was for us, the students, but it was more a lesson for those who don't have a fear of heights or for those who already know about bird watching and using binoculars. [...]The professor, who was a practiced birdwatcher, was very quiet and did not explain enough, but instead was out to see as much as possible himself. The professor certainly had good intentions when he went there with us, but it failed completely on my part. It is probably difficult for an experienced bird watcher to imagine the various students' perspectives when you do something like this, [...]. (Student 5 about the birding excursion)

The professor is described as a person who is primarily preoccupied with himself and his own birding interest and does not appear to be engaged with the students with a conscious pedagogical approach on how to optimally use the excursion as a learning opportunity. Further, for this student the material and location were also barriers to learning. The student's text indicates an expectation that professors will show students compassion and overcome these obstacles, rather than the idea that the students themselves should take the initiative in the situation and try to help themselves and each other.

Several students described their need for the professor to care about their learning and to look after them. In contrast, other students do not identify being looked after as an aspect in becoming interested and learning at all; they experience the same situation in a different way:

To see the birds in real life with a person who really knows what she or he is talking about is very fun to experience [...] If you look at how this birding was structured, it was primarily organized for us as students. He took us to an observation tower where we got to have our own binoculars we borrowed, and with professor there to support us we could ask him when we wondered about something. Then the fact we got to be involved the whole time during the lesson made me think it was fun from beginning to end. It felt like the professor wanted us to ask questions and the fact that he thought it was fun was apparent. (Student 6 about the birding excursion)

Student 6 understood the professor's research interests and deep knowledge as what is essential for the students to become interested and learn things. Unlike student 5, this student says that the professor is outgoing and the attention is on the students, and the student also describes that she felt involved.

At the seminar, students discussed the assignment. It became clear to the students that people could perceive the same teaching situation quite differently. In one of the student groups, Student V presented the birding excursion and then got two other students' perceptions about it:

V: [...] And then I thought it was pretty exclusive (laughs) I mean the professor had brought binoculars for everyone except two people. And it is also a way to start. $\mathrm{He}$ should have thought to include us a little more and adapt the teaching to our different conditions. We come from different cultures and don't all know much about birds or haven't been interested before, but we're there to learn.

$[\ldots]$ 
$\mathrm{U}$ : but I felt completely different on this bird excursion. I thought it was the most fun thing I've done.

Y: yes, that was my experience, too.

U: It was so fun, I was absolutely beaming. And I knew absolutely nothing about birds, absolutely zero. I felt that it depends on how you come at it. It also depends on how it starts, because I thought the professor should have binoculars for everyone, I mean I thought this was wrong from the start. I know nothing about this, I'm stupid, I thought (laughs). And then I just went and listened and tried to take in as much as possible about these birds. And I think I learned a lot, I thought it was great fun.

In the seminar discussion, the students shared their different experiences with each other, and they tried to find an interpretation of the professor's approach that could include all experiences. In other words, students' different experiences of the same event "forced" them to look for similarities. In the end of the seminar, the students described their own future roles, where concern for the children should come first and then compared this with the professor's teaching of students in their subject courses. One student said:

$\mathrm{U}$ : I think that most people who are natural scientists that I know are so incredibly interested in their subject areas. So birds are the best there is, stones, etc. I experienced the same thing it's the best thing that he/she can imagine. Right? And then they don't think about all students who can't follow.

This discussion led to the conclusion that in the same way that a preschool teacher prioritizes showing care for the children, the professor instead directed his/her "care" to the topic. The students reasoned that it could be a result of the different cultures that preschool teachers versus university science faculty found themselves in and are being trained in during their education. The conclusions that contributed to awareness were that the professor's actions could be understood as expressions of a cultural manifestation and that even within the scientific culture, "caring" appears along with strong emotional commitments, but it is directed elsewhere than the students. This increased the students' understanding of the professor and also helped the students who felt excluded or stupid to move these feelings and the burden of guilt off themselves. They could instead understand this experience as a manifestation of different cultures, which they expressed during discussion.

\section{Caring and children as boundary objects}

By using the students' reflective texts on science culture as a starting point for discussions and exchanging experiences, they became aware of that different teaching situations involved both positive and negative emotions for different students. The students contrasted university and preschool cultures in their discussion, and together they reasoned their way to the idea that there were commonalities between cultures; both a preschool teacher and a professor could be regarded as caring although the care was directed toward different objects. The concept of "care" can be said to function as a "boundary object" between the two cultures (Star and Griesemer 1989). Care is central to early childhood education and strongly associated with the preschool teaching profession. By inserting the concept of care in the description of the professor's teaching, the sense of distance between cultures was reduced temporarily, thereby reducing the chafing.

Children can also act as boundary objects for preschool student teachers. Several of them described in their texts that children at preschools are so interested in science and exploring their surroundings. This helps the students to look at science with "new eyes." 
The children become a bridge, a way to lower the threshold to academic science and increase the student teachers' motivations to learn the subject matter. Two students express below how the children act as boundary objects for their own knowledge acquisition in science:

Though I've always had a difficult time with science subjects, I think these topics are fun and interesting, especially in collaboration with the kids! (Student 7)

My interest in birds has actually increased because I see the possibility of working with this topic together with groups of children in the future. (Student 8)

We want to argue that caring for children in preschool includes ensuring that they are challenged intellectually, develop cognitively, as well as ensuring that they get food when they are hungry, comfort when they are sad or clean diapers when they are dirty. The subject knowledge preschool student teachers receive in the subject courses should thus contribute to the aspect of care that contributes to children's intellectual development. Thus, learning and care need not be separated. Instead, care as a common boundary object can act as a bridge between the preschool teacher education program and various subject areas and contribute to a common approach among professors, but with different entry points.

\section{The equalizing of power imbalances}

In the section "How the chafing emerges...," we demonstrated the cultural differences that emerge in the students' texts which we describe as amplifiers of the chafing between scientific and preschool culture, where the professor's exercise of power has been a part of this. But there are also examples in students' texts that highlight teachers who are actively working to minimize these power imbalances and thus may help to reduce the chafing. The students describe university professors with a more equitable approach to students. There are professors who attempt to use simpler, more everyday language, who are happy to answer the questions that the students have and, based on the questions asked, have the ability to provide new explanations. Students also describe examples of professors who invite the students into the learning and get them involved in teaching. Student 9 explains:

W turned to everyone in the classroom when he talked about the world and Swedish mammals. I felt that this lesson was really directed to me as an audience. He got us all involved in the lesson in a very good way by asking questions on various topics and letting us discuss them amongst ourselves and then saving the groups' ideas and responses on his computer (Student 9).

By saving the students' ideas and discussions on the computer at the lecture, the professor showed the students' views were important and it also helped the students feel empowered, like they were taking part in building the teaching.

There are also examples in students' texts where students at times went in and took command of the teaching when the professor held a lecture at a level that the majority of students could not assimilate:

We asked questions and the professor responded, but some of us still did not understand either photosynthesis or the stuff with formulas and "atoms". The professor repeated what she said several times but we still didn't understand. It all ended when a student who knew about this went up to the board and explained it to us in a way we understood. (Student 10) 
This quote shows a classroom climate where the students feel that they can ask many questions and can also participate and contribute to the actual teaching. The professor took a step back and handed over control of the situation to a student. The student acted as a bridge between the professor and the other students, and through this, the power shifted in the classroom; students became more equal with the teacher. It is worth noting that the same teacher by different students can be described either as one who is abusing his/her position of power or works to equalize the power hierarchy between teachers and students.

As discussed earlier, a majority of preschool student teachers opted to examine their own university classes when they were given the task, "capture the science culture." When it became clear to them that this was a possibility, there was an emotional outpouring in the classroom. The opportunity to write about their experiences, which in most cases have been based on a subordinate position in relation to the subject and/or the science teacher, gave rise to "revenge." Students could also analyze and criticize the power and put words to their experiences and feelings, something that contributed to empowerment. The assignment itself thus put the power structure in flux. This allowed students to take a position, with the right to point to problems in science teaching, which meant that they could move the negative feelings from themselves. But there is also a risk with this type of task that the teacher must be aware of. It may not stop at merely offering an opportunity to express negative views about individual university professors; it may also be used to justify an approach where students do not engage in their studies and learn the knowledge content. Monitoring and analysis are necessary so that students are given the opportunity to, at each individual's emotional pace, move on to a cognitive level. Then, students can draw conclusions that do not stop at their own experiences but are able to see and understand more general patterns.

\section{Conclusions}

In the preschool teacher programme we have studied, the students take science courses for two semesters. These courses are imbedded with values and norms belonging to the science culture. Earlier research has highlighted the fact that preschool teachers often avoid teaching chemistry, physics and technology due to low self-esteem and too little training regarding these subjects. By using the concept of cultural contrast, cultural borders and chafing borderlands this study moves focus from students' shortcomings regarding lack of knowledge in science to the cultural differences between science and preschool culture, which give rise to resistance and chafing and hinder students' learning.

By examining how preschool student teachers perceived their university education in science, we were able to identify how chafing was expressed between the two cultures:

- University teachers' ways of teaching manifest the natural sciences as elitist with objective facts to learn, something for the smart ones. For others, it creates feelings of stupidity and inabilities to understand. The scientific language where concepts have precise definitions and are free from emotions also contributed to feelings of alienation in our group of students.

- The students are familiar with, and have feelings of, belonging to the preschool culture, a culture less hierarchical than science. They define their science content knowledge needs to that of what the children are expected to learn. Science that is at a deeper level has a negative affect on their motivation which causes their resistance to learning. 
The students are in a subordinate position in several ways: in relation to science faculty, in relation to natural science subjects, as well as having chosen a feminine-coded profession (Hirdman 2001). Thus, gender order is a significant aspect, cooperating in chafing between science and preschool culture and is in a way double present by the masculine coded science versus the feminine-coded preschool culture together with the gender of these students (where there are a majority of female students).

The results provide possible ways to overcome or reduce this chafing:

- One way to smooth out the hierarchy was the task in itself. The students' critical examination of the natural science culture gave rise to their feelings of empowerment.

- The university teacher's way of acting and teaching is essential for bridging between the two cultures. That happens when the teacher is willing to "step down from the pedestal," base the teaching on the students' experiences and let them take a more active role in the classroom. The teacher creates a classroom atmosphere, where the students get the opportunity to explain to each other, without the risk of being considered stupid, ask questions and together try to define "tricky" concepts.

- Using care and children as boundary objects explicitly in the educational setting to bridge between the science and preschool cultures can be a fruitful way of diminishing chafing.

\section{Chafing as a pedagogical tool to enhance preservice teachers' cultural understandings}

We have described the preschool teacher education program as a tension between different cultures, where there is chafing at the borders. An awareness of these different cultures and the chafing between them can be an asset in teacher education for all participants. The different cultures affect how students perceive their education and their expectations for the instruction they receive. If the students develop gender awareness and gain knowledge of sociocultural aspects of science, it may also help reduce chafing.

The chafing that occurs can be a barrier to student engagement and learning in science, but it can also be seen as an educational point of access. Teacher students that have come across these chafing borderlands and also got insights about the different cultures can easier understand children's different approaches to the subject.

Another implication of the results of this study is that science faculty has to be aware of and not abuse the unequal power relationship in teaching high-status subjects. Science faculty, but also faculty within other areas in preschool teacher education, should realize that preschool teacher students during the major part of their education internalize a culture different from the science culture. It becomes an obstacle if this cultural shift will be unspoken. One way to increase the university teachers' awareness about these different cultures in the education is to open up for auscultation, across disciplines, on each other's teaching moments. However, we want to stress that our suggestions should not be interpreted as one should strive for a uniform culture in preschool teacher education but instead explicitly express that these cultural differences exist. This also makes the norms and values of a specific culture possible to challenge and thus eventually change. 
Funding Funding was provided by Vetenskapsrådet, the Swedish Research Council (Grant No. 721-2010-5156).

Open Access This article is distributed under the terms of the Creative Commons Attribution 4.0 International License (http://creativecommons.org/licenses/by/4.0/), which permits unrestricted use, distribution, and reproduction in any medium, provided you give appropriate credit to the original author(s) and the source, provide a link to the Creative Commons license, and indicate if changes were made.

\section{Appendix 1: Capture the scientific culture through an observation of science teaching or an examination of teaching material texts, a laboratory or an excursion assignment}

You will review a teaching period (lecture, class, seminar, laboratory work, exercise, excursion, etc.), a passage from a textbook or other instructional materials. For the teaching activity, you can select any of your current classes or conduct an observation of science lessons at a partner school. Alternatively, you can choose to analyze a section of any scientific teaching material (from the university or a school).

1. First, give a brief description of the teaching period or instructional materials selected for review. If you review a text, you should attach a copy of the text or indicate the source with page references.

2. Then, use the didactic questions, "what, why, how and for whom?" as starting points for your review, and write down your analysis.

Based on the analysis that you made according to the four questions, you should try to "capture" scientific culture and get at what stories are told in parallel with the knowledge material conveyed. Write down your reflections.

\section{References}

Aikenhead, G. S. (2001). Students' ease in crossing cultural borders into school science. Science Education, 85(2), 180-188. https://doi.org/10.1002/1098-237X(200103)85:2\%3c180:AID-SCE50\%3e3.0.CO;2-1.

Akkerman, S. F., \& Bakker, A. (2011). Boundary crossing and boundary objects. Review of Educational Research, 81(2), 132-169. https://doi.org/10.3102/0034654311404435.

Andersson, K. (2012). "It's funny that we don't see the similarities when that's what we're aiming for"Visualizing and challenging teachers' stereotypes of gender and science. Research in Science Education, 42(2), 281-302. https://doi.org/10.1007/s11165-010-9200-7.

Andersson, K., \& Gullberg, A. (2014). What is science in preschool and what do teachers have to know to empower the children? Cultural Studies of Science Education, 9(2), 275-296. https://doi.org/10.1007/ s11422-012-9439-6.

Braun, V., \& Clarke, V. (2006). Using thematic analysis in psychology. Qualitative Research in Psychology, 3, 77-101. https://doi.org/10.1191/1478088706qp063oa.

Brickhouse, N. W. (2001). Embodying science: A feminist perspective on learning. Journal of Research in Science Teaching, 38(3), 282-295. https://doi.org/10.1002/1098-2736(200103)38:3\%3c282:AIDTEA $1006 \% 3 \mathrm{e} 3.0 . \mathrm{CO} ; 2-0$.

Butler, J. (1990). Gender trouble. Feminism and the subversion of identity. London: Routledge.

Capobianco, B. (2007). Science teachers' attempts at integrating feminist pedagogy through collaborative action research. Journal of Research in Science Teaching, 44(1), 1-32. https://doi.org/10.1002/ tea. 20120 . 
Cobern, W. W., \& Aikenhead, G. S. (1998). Cultural aspects of learning science. In B. J. Fraser \& K. G. Tobin (Eds.), International handbook of science education (pp. 39-52). London: Kluwer Academic Publishers. https://doi.org/10.1007/978-94-011-4940-2_3.

Corsaro, W. (2005). The sociology of childhood. Thousand Oaks, CA: Pine Forge Press.

Costa, V. B. (1995). When science is "another world": Relationships between worlds of family, friends, school, and science. Science Education, 79(3), 313-333. https://doi.org/10.1002/sce.3730790306.

Fensham, P. J. (1991). Science education in early childhood education: A diagnosis of a chronic illness. Australian Journal of Early Childhood, 16(3), 3-8.

Fleer, M. (2006). Meaning-making science: Exploring the sociocultural dimensions of early childhood teacher education. In K. Appleton (Ed.), Elementary science teacher education: International perspectives on contemporary issues and practice (pp. 107-124). Mahwah, NJ: L. Erlbaum Associates.

Halldén, G. (2007). Den moderna barndomen och barns vardagsliv [The modern childhood and children's everyday life]. Stockholm: Carlsson.

Haraway, D. (1988). Situated knowledges: The science question in feminism and the privilege of partial perspective. Feminist Studies, 14, 575-599. https://doi.org/10.2307/3178066.

Hasse, C. (2015). An anthropology of learning: On nested frictions in cultural ecologies. Dordrecht: Springer. https://doi.org/10.1007/978-94-017-9606-4.

Hasse, C., \& Trentemøller, S. (2009). The method of culture contrast. Qualitative Research in Psychology, 6(1-2), 46-66. https://doi.org/10.1080/14780880902900903.

Hirdman, Y. (2001). Genus: om det stabilas föränderligas former [Gender: On the changeable forms of the stable]. Malmö: Liber.

Hussénius, A., Andersson, K., \& Gullberg, A. (2015). Spotting the science culture: Integrating gender perspectives into science courses. International Journal of Gender, Science and Technology, 7(1), 91-103.

Johansson, E., \& Pramling Samuelsson, I. (2001). Omsorg: en central aspekt av förskolepedagogiken. Exemplet måltiden [Care: A key aspect of early childhood education. The meal as an example]. Pedagogisk Forskning i Sverige, 6(2), 81-101.

Kang, E. J. S., Bianchini, J. A., \& Kelly, G. J. (2013). Crossing the border from science student to science teacher: Preservice teachers' views and experiences learning to teach inquiry. Journal of Science Teacher Education, 24, 427-447. https://doi.org/10.1007/s10972-012-9317-9.

Krogh, L. B., \& Thomsen, P. V. (2005). Studying students' attitudes towards science from a cultural perspective but with a quantitative methodology: Border crossing into the physics classroom. International Journal of Science Education, 27(3), 281-302. https://doi.org/10.1080/09500690412331314469.

Lpfö 98 Läroplan för förskolan, reviderad 2010 [Curriculum for the Preschool Lpfö 98]. Stockholm: Skolverket.

Månsson, A. (2000). Möten som formar: interaktionsmönster på förskolan mellan pedagoger och de yngsta barnen i ett genusperspektiv [Meetings that shape: Gender perspectives on interaction patterns in preschool between the educators and the youngest children]. Malmö: Institutionen för pedagogik, Lärarutbildningen, Malmö högskola.

Mulholland, J., \& Wallace, J. (2003). Crossing borders: Learning and teaching primary science in the preservice to in-service transition. International Journal of Science Education, 25(7), 879-898. https:// doi.org/10.1080/09500690305029.

Phelan, P., Davidson, A. L., \& Cao, H. T. (1991). Students multiple worlds: Negotiating the boundaries of family, peer, and school cultures. Anthropology \& Education Quarterly, 22, 224-250. https://doi. org/10.1525/aeq.1991.22.3.05x1051k.

Scantlebury, K. (2012). Still part of the conversation: Gender issues in science education. In B. Fraser, C. McRobbie, \& K. Tobin (Eds.), Second international handbook of science education (pp. 499-512). New York: Springer. https://doi.org/10.1007/978-1-4020-9041-7_34.

Schmader, T., \& Johns, M. (2003). Converging evidence that stereotype threat reduces working memory capacity. Journal of Personality and Social Psychology, 85(3), 440-452. https://doi. org/10.1037/0022-3514.85.3.440.

Sible, J. C., Wilhelm, D. E., \& Lederman, M. (2006). Teaching cell and molecular biology for gender equity. CBE Life Sciences Education, 5, 227-238. https://doi.org/10.1187/cbe.05-08-0096.

Spector-Levy, O., Kesner Baruch, Y., \& Mevarech, Z. (2013). Science and scientific curiosity in pre-school: The teacher's point of view. International Journal of Science Education, 35(13), 2226-2253. https:// doi.org/10.1080/09500693.2011.631608.

Star, S. L., \& Griesemer, J. R. (1989). Institutional ecology, 'translations' and boundary objects: Amateurs and professionals in Berkeley's Museum of Vertebrate Zoology. Social Studies of Science, 19, 387420. https://doi.org/10.1177/030631289019003001.

Sundberg, B., \& Ottander, C. (2013). The conflict within the role: A longitudinal study of preschool student teachers' developing competence in and attitudes towards science teaching in relation to 
developing a professional role. Journal of Early Childhood Teacher Education, 34, 80-94. https://doi. org/10.1080/10901027.2013.758540.

Swedish National Agency for Education. (2016). https://www.skolverket.se/statistik-och-utvardering/stati stik-i-tabeller/forskola. Accessed 17 Feb 2019.

Swedish School Inspectorate. (2012). Förskola, före skola - lärande och bärande. Kvalitetsgranskningsrapport om förskolans arbete med det förstärkta pedagogiska uppdraget 2017:7 [Preschool, before school - learning and carrying. Report 2017:7]. Stockholm.

Vallberg Roth, A-C. (2002). De yngre barnens läroplanshistoria [The younger children's curriculum history]. Lund: Studentlitteratur.

Publisher's Note Springer Nature remains neutral with regard to jurisdictional claims in published maps and institutional affiliations.

Kristina Andersson is an associate professor in Science Education at Uppsala University, Sweden. Her main research interest is gender and feminist perspectives on science and science education. She has been a guest researcher at the Centre for Gender Research at Uppsala University since 2008.

Annica Gullberg holds a Ph.D. in genetics. During the last 20 years, her research interest has been in science education, especially with a gender perspective. Annica is a senior lecturer at the University of Gävle and a guest researcher at the Centre for Gender Research at Uppsala University.

Anna T. Danielsson is a professor in education at Uppsala University. Her research interests are centered around issues of identity, gender and power in science education.

Kathryn Scantlebury is a professor in the Department of Chemistry and Biochemistry at the University of Delaware, Director of Secondary Education in the College of Arts and Sciences. Her research interests focus on gender issues in various aspects of science education, including urban education, preservice teacher education, teachers' professional development and academic career paths in academe. Scantlebury is a guest researcher at the Centre for Gender Research at Uppsala University, Co-Editor in Chief for the journal Gender and Education and co-editor of two book series for BrilllSense Publishers.

Anita Hussénius is an associate professor in chemistry and researcher at the Centre for Gender Research at Uppsala University. Her main research interest is about gender and feminist perspectives on science and science education. More specifically, her research is focusing on cultural aspects, i.e., discipline specific values and underlying assumptions of what is regarded as important knowledge and skills, and how such values and assumptions are mediated explicitly as well as implicitly. 